\title{
VLIV VODORETENČNÍCH PŘÍSAD NA PŘÍDRŽNOST MALTY K PODKLADU
}

\author{
INFLUENCE OF WATER-RETENTIVE ADMIXTURES ON THE \\ ADHESIVE STRENGTH OF MORTARS
}

Tomáš Žižlavský1

${ }^{1}$ Vysoké učení technické v Brně, Fakulta stavební, Veveří 331/95, 60200 Brno

\begin{abstract}
Abstrakt
Článek sleduje vliv biopolymerních viskozitu modifikujících přísad s vodoretenční funkcí na přídržnost malt na bází přirozeného hydraulického vápna k podkladu z plných pálených cihel vysušených nebo nasycených vodou. Při nanesení na nasycený podklad je pozorován nepř́iznivý vliv nadměrně vysoké retence vody v maltě a vysokého vodního součinitele, zatímco na suchém podkladu mají tyto vlastnosti pozitivní vliv. Je sledován také způsob porušení při odtrhové zkoušce, kde je častější výskyt porušení v maltě u malt na vysušeném podkladu. Každá ze zkoumaných př́sad měla pozitivní vliv na př́ídržnost malty k podkladu alespoň v jednom ze sledovaných př́ípadů.
\end{abstract}

\section{Klíčová slova}

Přirozené hydraulické vápno, př́ísada, přídržnost, retence vody

\begin{abstract}
The article studies the influence of viscosity-modifying admixtures with water-retentive function on the adherence of natural hydraulic lime-based mortars to traditional fired-clay brick substrate. The substrate was either dried or water-saturated. High water retention value and water/binder ratio led to inferior performance while applied on saturated substrate. On the other hand those properties were found beneficial on the dried substrate. The failure in the mortar during the pull-off test is far more common while the mortars are applied on dried substrate. Each of the admixtures studied proved to be useful in improving the performance of the mortar in at least one of the studied conditions.
\end{abstract}

\section{Key words}

Natural hydraulic lime, admixture, adhesive strength, water retention

\section{1 ÚVOD}

Charakteristiky spoje malty s podkladní vrstvou jsou ovlivněny širokou škálou faktorů, které lze rozdělit do třech kategorií: vlastnosti malty (např. zpracovatelnost, retence vody v maltě, ...), vlastnosti podkladu (nasákavost, struktura povrchu, ...) a také způsobem provedení. Vhodnou zpracovatelností malty lze docílit lepšího styku s podkladem především dokonalejším vyplněním povrchových pórů podkladu maltou, přeneseně tedy zvýšením styčné plochy a vytvořením ,zámků“. Měly by být tedy voleny co nejtekutější malty vhodné pro cílené použití [1-5]. Retence vody v maltě je úzce spjata s nasákavostí podkladních vrstev. Čím nasákavější podklad tím vyšší požadavek na vodoretenční schopnost malty, aby se zabránilo nadměrnému (a rychlému) vysychání, které vede ke vzniku trhlin, a v prípadě hydraulických pojiv k zastavení hydratace, což má výrazný vliv na kvalitu výsledné malty $[6,7]$.

Zlepšení vodoretenčních schopností malt lze dosáhnout vhodnými přísadami či příměsemi. V případě cementové malty je historicky nejobvyklejší použití vápenného hydrátu ve výsledném poměru 1:1:6 prrípadně 1:2:9 objemově (cement:vápno:kamenivo) [1,6]. S rozmachem chemického průmyslu v průběhu 20. století a vývojem prrísad do betonu se v 70. letech začaly jako vodoretenční přísady do malt a betonu využívat ethery celulózy [7]. Jsou však vyvíjeny stále další polymery s podobnými vlastnostmi, které mohou postrádat některé z nepř́iznivých vedlejších účinků jako je např́iklad retardace hydratačních reakcí [8].

V práci jsou zkoumány malty modifikované hydroxypropylmethyl derivátem celulózy (HPMC), hydroxypropyl deriváty chitosanu a guarové gumy (HPCH resp. HPG), gumou diutanovou (DG) a alginátem 
sodným (ALGNA). Deriváty obsahující hydroxypropylovou skupinu byly zvoleny, aby byl minimalizován vliv rozdílných skupin na vlastnosti malty [9].

HPG a HPCH mají podobné vlastnosti jako HPMC, avšak nižší účinnost. [10, 11]. Alginát sodný má pouze malý vliv na vlastnosti malty v čerstvém stavu, ale ve vyšších dávkách výrazně ovlivňuje strukturu výsledné malty a tím i její výsledné vlastnosti [12]. Diutanová guma, blízký př́ibuzný gumy xanthanové s výrazně nižší citlivostí na koncentraci bivalentních iontů a teplotu a také gumy wellanové, ve vápenných maltách výrazně zvyšuje vodní součinitel [12] a ovlivňuje reologii modifikované malty, především podporuje tixotropii a snižuje mez toku, tedy dává vzniknout „tekutějšsi“" maltě.

\section{METERIÁL A METODY}

Malty byly připraveny z prrirozeného hydraulického vápna třídy NHL 3.5 dle EN 459 (Zement- und Kalkwerke Otterbein GmbH \& Co. KG) a převážně křemičitého písku frakce 0-4 mm (Českomoravský štěrk a.s., Hulín). Tyto byly smíchány v objemovém poměru 1:1 spolu s prŕsadou dle Tab. 1 a vodním součinitelem uvedeným tamtéž, aby byla dosažena konzistence $160 \pm 5 \mathrm{~mm}$ na střásacím stolku dle EN 1015-3. Byla stanovena retence vody v čerstvé maltě (WRV) a malty byly aplikovány na plné pálené cihly (Zlínské cihelny s.r.o., Žopy, nasákavost $21 \%$ dle údajů výrobce), které byly bud' vysušené (D), a nebo nasycené vodou (W). Cihly se vzorky byly následně ponechány v laboratorních podmínkách $\left(21 \pm 2{ }^{\circ} \mathrm{C}, 55 \pm 5 \% \mathrm{RH}\right)$ až do stárí 90 dní, kdy byly na cca 14 dní uloženy v prostředí s vysokou relativní vlhkostí. Byl vizuálně zhodnocen povrch malt a následně byly odvrtány terče o průměru $50 \mathrm{~mm}$ pro zkoušku přídržnosti zatvrdlé malty k podkladu, která byla provedena v souladu s EN 1015-12.

Tab. 1 Přísady, jejich dávkování, vodní součinitel a retence vody v čerstvé maltě.

\begin{tabular}{|c|c|c|c|c|c|}
\hline Zkratka & Chemické složení & Výrobce & $\begin{array}{c}\text { Dávka } \\
\text { [\%] }\end{array}$ & $\begin{array}{c}\text { Vodní } \\
\text { součinitel } \\
{[-]}\end{array}$ & $\begin{array}{l}\text { WRV } \\
{[\%]}\end{array}$ \\
\hline REF & - & - & - & 0.600 & 90.53 \\
\hline \multirow{3}{*}{ НРСН } & \multirow{3}{*}{$\begin{array}{l}\text { hydroxypropyl } \\
\text { chitosan }\end{array}$} & \multirow{3}{*}{$\begin{array}{c}\text { Kraeber } \\
\& \mathrm{Co} \\
\mathrm{GmbH}\end{array}$} & 0.1 & 0.725 & 90.42 \\
\hline & & & 0.5 & 0.850 & 91.36 \\
\hline & & & 1.0 & 0.900 & 89.51 \\
\hline \multirow{3}{*}{ HРMC } & \multirow{3}{*}{$\begin{array}{l}\text { hydroxypropylmethyl } \\
\text { celulóza }\end{array}$} & \multirow{6}{*}{$\begin{array}{l}\text { Lamberti } \\
\text { s.p.a. }\end{array}$} & 0.1 & 0.725 & 91.78 \\
\hline & & & 0.5 & 0.850 & 96.84 \\
\hline & & & 1.0 & 1.000 & 98.36 \\
\hline \multirow{3}{*}{ HPG } & \multirow{3}{*}{$\begin{array}{l}\text { hydroxypropyl } \\
\text { guarová guma }\end{array}$} & & 0.1 & 0.650 & 88.49 \\
\hline & & & 0.5 & 0.800 & 95.63 \\
\hline & & & 1.0 & 0.925 & 98.28 \\
\hline \multirow{3}{*}{ ALGNA } & \multirow{3}{*}{ alginát sodný } & \multirow{3}{*}{$\begin{array}{l}\text { Sigma- } \\
\text { Aldrich, } \\
\text { Co }\end{array}$} & 0.1 & 0.675 & 85.69 \\
\hline & & & 0.5 & 0.700 & 92.78 \\
\hline & & & 1.0 & 0.875 & 91.63 \\
\hline \multirow{3}{*}{ DG } & \multirow{3}{*}{ diutanová guma } & \multirow{3}{*}{$\begin{array}{c}\text { CP } \\
\text { Kelco. }\end{array}$} & 0.1 & 0.800 & 86.61 \\
\hline & & & 0.5 & 0.950 & 98.23 \\
\hline & & & 1.0 & 1.100 & 97.53 \\
\hline
\end{tabular}

\section{VÝSLEDKY A DISKUSE}

\section{Vizuální posouzení}

Již po nanesení malty na podklad byly pozorovatelné značné rozdíly mezi jednotlivými maltami, především při aplikaci na vysušené cihly. V závislosti na rychlosti vysychání malty a následném zrání vykazovaly jednotlivé kombinace malt a podkladů několik typů poruch ve formě trhlin, které jsou na Obr. 1 zachyceny po 90 dnech zrání. Při aplikaci na nasycené cihly nebylo, kromě rozdílné struktury výsledného povrchu odkazujícího na rozdílné reologické vlastnosti malty, pozorovány výraznější rozdíly v chování jednotlivých malt a vývinu 
poruch. Na vysušeném podkladu, který výrazně odsával volnou vodu z malty, došlo k vývinu několika typů trhlin. Dva z nich byly pozorovatelné již v počátečních fázích zrání, at' již přímo po nanesení, nebo před začátkem tvrdnutí směsi. Tyto byly způsobeny rychlým vyschnutím malty [5]. Třetím typem jsou trhliny, které se objevily až v průběhu tvrdnutí aplikovaných malt. Prvním typem trhlin, který se projevoval v maltách modifikovaných nejnižší dávkou přísady a tedy i nejnižší hodnotou WRV, je několik trhlin kolmých na delší hranu podkladní cihly, které rozdělily maltu na přibližně stejně velké segmenty jak je patrné na Obr. 1 (b) a (c). $\mathrm{S}$ rostoucí dávkou př́sady, a tedy i WRV a především vodím součinitelem, došlo k vývinu druhého typu trhliny - hlavní podélná trhlina přibližně středem vzorku, která se rozvětvuje větším množstvím drobných trhlin, a rozděluje aplikovanou plochu na přibližně 6 segmentů jako v prrípadě vzorků na Obr 1 (d) a (e). S rostoucím WRV, jako v případě HPG (Obr. 1 (h)) nebo HPMC (Obr. 1 (i)), dochází ke zmenšení šíŕky těchto trhlin a jejich postupnému vymizení. Na př́kladu těchto velmi podobných malt můžeme vidět, že ne jen WRV, ale i vodní součinitel, který je v př́ípadě HPMC 0.5 (Obr. 1 (i)) větší, má vliv na praskání malty. Po několika dnech od nanesení malt se začaly objevovat další drobné trhlinky i na vzorcích, které byly do té doby bez porušení, a které jsou způsobené pravděpodobně různou tloušt'kou podkladu. V př́ípadě malt modifikovaných diutanovou gumou se v této fázi zrání objevilo velké množství tenkých, izolovaných trhlinek neprostupujících celou tloušt'kou malty (Obr 1 (j)).

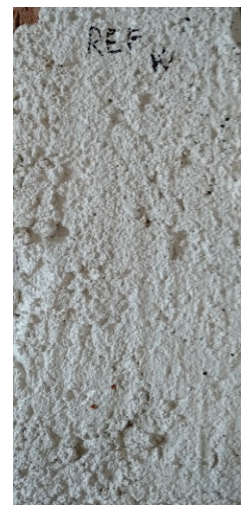

(a) REF W

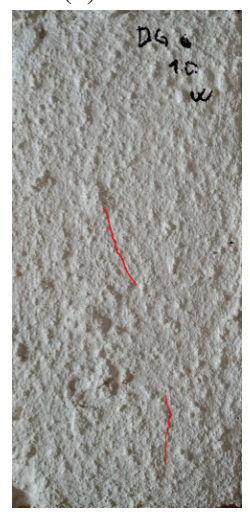

(f) $\mathrm{DG} 1.0 \mathrm{~W}$

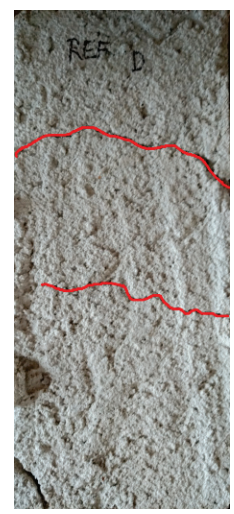

(b) REF D

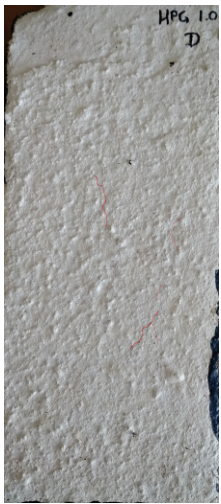

(g) HPG $1.0 \mathrm{D}$

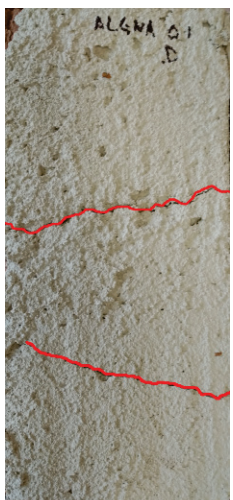

(c) ALGNA $0.1 \mathrm{D}$

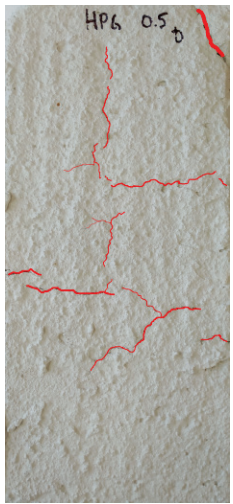

(h) HPG $0.5 \mathrm{D}$

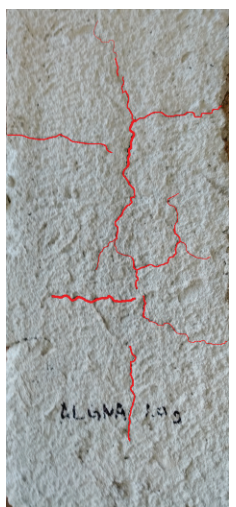

(d) ALGNA 1.0 D

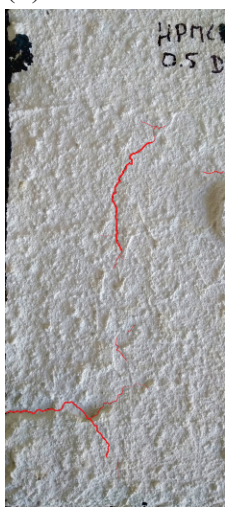

(i) HPMC $0.5 \mathrm{D}$

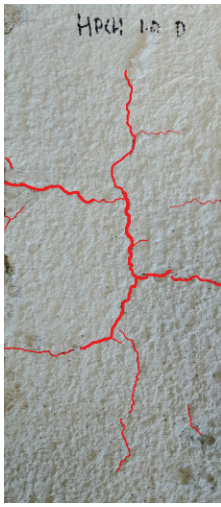

(e) $\mathrm{HPCH} 1.0 \mathrm{D}$

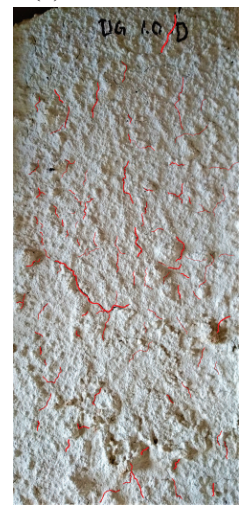

(j) DG $1.0 \mathrm{D}$

Obr. 1 Ukázka různých poruch malt aplikovaných na nasycený (W) a vysušený (D) poklad.

\section{Př́́držnost malty k podkladu}

Př́idržnost malty k podkladu stanovená na terčích o průměru $50 \mathrm{~mm}$ je uvedena v grafech na Obr. 2. Ve většině př́ípadů bylo dosaženo vyšší hodnoty pro malty nanesené na nasycený podklad (Obr. 2 (a)), což je v souladu s běžnou praxí namáčení cihel při zdění/vlhčení podkladu před aplikací omítky i s výsledky prezentovanými v literatuře $[2,3,5,6]$. Ve vztahu mezi přídržností a množstvím přísady jsou pozorovatelné dva typy chování: znatelné zvýšení př́idržnosti již po přídavku malého množství př́isady následované poklesem př́idržnosti s rostoucím dávkováním (HPCH, ALGNA, DG), anebo počáteční pokles přídržnosti následovaný jejím růstem 
s vyšší dávkou přísady (HPMC a HPG). Při aplikaci malty na nasycený podklad není zjevný výrazný vliv WRV nebo vodního součinitele na výsledné př́idržnosti, toto je nejzjevnější v př́ípadě dvojic HPCH 0.1 a HPMC 0.1 a HPG 0.1 a ALGNA 0.1 , které mají vždy v páru velmi podobné sledované vlastnosti v čerstvém stavu, avšak rozdíl v jejich př́držnosti je až 50\%. Toto bude pravděpodobně způsobeno rozdílnou viskozitou malty, kdy by vyšší viskozita měla zajistit i vyšší př́držnost $[5,7]$. Vliv jednotlivých prrísad na reologické vlastnosti past na bázi NHL byl sledován dříve $[13,14]$ a prezentované výsledky tuto teorii podporují. Pokles přídržnosti pro maltu HPMC 1.0 a malty modifikované DG je způsoben extrémně vysokým (v př́ípadě DG 1.0 téměř dvojnásobným) vodním součinitelem spolu s nasycením podkladu, který se pak chová jako téměř nenasákavý [2, 5].

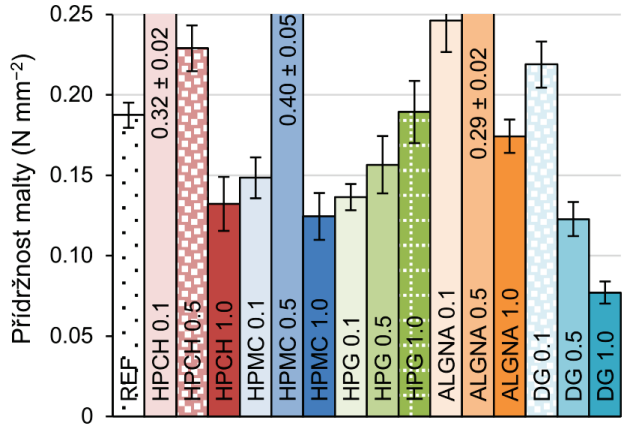

(a)

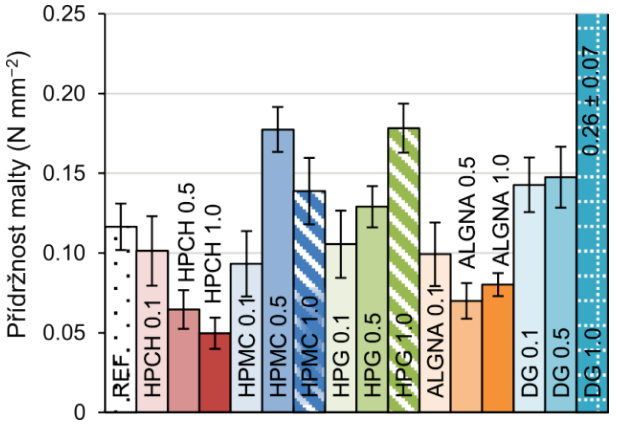

(b)

Obr. 2 Přídržnost malty k nasycenému (a) a vysušenému (b) podkladu. Šikmou šrafou jsou zvýrazněny případy, kdy došlo k porušení v maltě, plátováním, kde došlo k poruše v maltě v 50 \% př́padů a mřížkou případy, kdy došlo k poruše částečně v maltě a částečně v adhezi.

Při aplikaci na suchý, nasákavý podklad zůstal trend vývinu přídržnosti stejný pro většinu přísad s výjimkou DG. Je zde zjevný pozitivní vlil vysoce vodoretenčních př́sad (DG, HPG, HPMC), které dosáhly podobných přídržností jako v případě aplikace na nasycené cihly. Samotný vliv zvýšeného vodního součinitele, doporučovaného v literatuře $[2,3,5]$, nebyl potvrzen, když přídržnosti např. HPCH 1.0 a ALGNA 1.0 byly nižší než u malt s vyšším WRV, i přes výrazně vyšší vodní součinitel. Přestože, jak uvádí Ritchie a Davidson [3], úprava WRV vede ke změně i v dalších vlastnostech malty (vodní součinitel, viskozita, obsah vzduchu ...) a je tedy obtížné sledovat vliv pouze WRV bez ovlivnění dalších vlastností, je z výsledků patrný pozitivní vliv zvýšeného WRV na př́držnost malty k nasákavému podkladu $[2,3]$. U malt s 1\% prŕ́davkem HPMC a HPG došlo při odtrhové zkoušce k porušení v maltě (Obr. 3 (c)) a tedy přídržnost bude ještě vyšší než udávané hodnoty. K této poruše mohlo dojít vlivem vlhkostního gradientu v maltě, kdy je voda transportována směrem k nasákavému podkladu a může dojít ke spálení malty ve vyšších vrstvách [15], nebo vznikem smršt’ovacích trhlin, které se však neprojevily na povrchu. U malt s $1 \%$ př́idavkem DG došlo k částečnému porušení v maltě a ve styku, jak je patrné z Obr. 3 (b), vlivem mikrotrhlin prostupujících maltou, zvýrazněných na Obr. 2 (j).

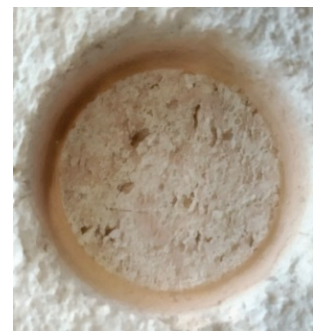

(a) $\mathrm{HPCH} 1.0 \mathrm{~W}$

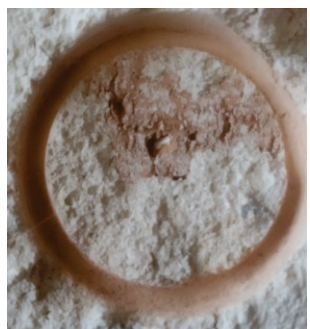

(b) DG $1.0 \mathrm{D}$

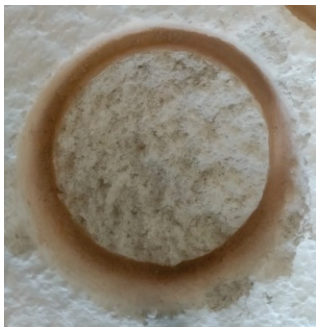

(c) HPMC $1.0 \mathrm{D}$

Obr. 3 Př́íklady porušení: (a) v adhezi, (b) v adhezi a maltě zároveň, (c) v maltě. 


\section{ZÁVĚR}

Práce zkoumá vliv biopolymerních, viskozitu modifikujících přísad s vodoretenční funkcí na př́idržnost malt na bází prrirozeného hydraulického vápna k podkladu z plných pálených cihel vysušených nebo nasycených vodou. Př́idavkem přísady došlo mimo zvýšení vodoretenčních vlastností malty i k nárůstu vodního součinitele nutného pro dosažení stejné konzistence. Malty s vysokou retencí vody a vyšším vodním součinitelem vykazovaly při nanesení na vysušené cihly dobrou odolnost proti vývinu trhlin, které se u malt s méně účinnou př́sadou na vysušeném podkladu objevily téměř okamžitě po aplikaci vlivem nadměrně rychlého vysychání a smršt'ování malty. Přídržnost malty $\mathrm{k}$ nasycenému podkladu byla podpořena především vyšší viskozitou některých malt a snížena kombinací vysoké retence vody spolu s vysokým vodním součinitelem. Na nasákavém podkladu naopak vysoká retence vody a vodní součinitel vedly k lepším prrídržnostem modifikovaných malt. Ze sledovaných př́sad měly každá pozitivní vliv na prrídržnost malty k podkladu, alespoň vjednom ze zkoumaných př́ípadů.

Úpravou malt pomocí viskozitu modifikujících přísad s vodoretenční funkcí lze docílit výrazného snížení vlivu neprríznivých charakteristik podkladu na výsledné vlastnosti systému. Tyto výsledky však nelze generalizovat do různých tvrzení, např. ,čím vyšší retence vody v maltě tím lepší spoj malty s podkladem“, ale je třeba $\mathrm{k}$ jednotlivým př́ípadům přistupovat individuálně.

\section{Poděkování}

Studie byla vypracována za přispění projektu specifického výzkumu FAST-J-21-7479.

\section{Použité zdroje}

[1] Johnson JB, Withey MO, Aston J. Johnson's Materials of Construction Rewritten by. 5th ed. New York: John Wiley \& Sons, Inc.; 1918.

[2] Parsons DE. Watertightness and Traverse Strength of masonry walls. Washingto, D.C.: Structural Clay Products Institute, Inc.; 1939.

[3] Ritchie T, Davison J. Factors Affecting Bond Strength and Resistance to Moisture Penetration of Brick Masonry. Symp. Mason. Test., West Conshohocken, PA: ASTM International; 1963, p. 16-30. https://doi.org/10.1520/STP39541S.

[4] Fishburn CC. Effect of Mortar Properties On Strength of Masonry. Natl. Bur. Stand. Monogr., vol. 36, Washington, D.C.: 1961.

[5] Högberg E. MORTAR BOND Rapport från Byggforskningen, Stockholm. Stockholm: 1967.

[6] Palmer LA, Hall JV. Durability and strength of bond between mortar and brick. Bur Stand J Res 1931;6:473-92. https://doi.org/10.6028/jres.006.032.

[7] Zhi Z, Ma B, Jian S, Su L, Guo Y, Chen F. Research on the interface and microstructure of thin layer mortar. ZKG Int 2016;69:62-9.

[8] Zhang G, Zhao J, Wang P, Xu L. Effect of HEMC on the early hydration of Portland cement highlighted by isothermal calorimetry. $J$ Therm Anal Calorim 2015;119:1833-43. https://doi.org/10.1007/s10973014-4346-6.

[9] Ou ZH, Ma BG, Jian SW. Influence of cellulose ethers molecular parameters on hydration kinetics of Portland cement at early ages. Constr Build Mater 2012;33:78-83. https://doi.org/10.1016/j.conbuildmat.2012.01.007.

[10] Govin A, Bartholin M-C, Biasotti B, Giudici M, Langella V, Grosseau P. Modification of water retention and rheological properties of fresh state cement-based mortars by guar gum derivatives. Constr Build Mater 2016;122:772-80. https://doi.org/10.1016/j.conbuildmat.2016.06.125.

[11] Ustinova Y V., Nikiforova TP. Cement Compositions with the Chitosan Additive. Procedia Eng 2016;153:810-5. https://doi.org/10.1016/j.proeng.2016.08.247.

[12] Žižlavský T, Vyšvařil M, Bayer P, Rovnaníková P. Microstructure of biopolymer-modified aerial lime mortars. MATEC Web Conf 2020;322:01023. https://doi.org/10.1051/matecconf/202032201023.

[13] Žižlavský T, Vyšvařil M, Rovnaníková P. Rheology of natural hydraulic lime pastes modified by nontraditional biopolymeric admixtures. Epa - J Silic Based Compos Mater 2019;71:204-9. https://doi.org/10.14382/epitoanyag-jsbcm.2019.36.

[14] Zizlavsky T, Vysvaril M, Rovnanikova P. Rheological study on influence of hydroxypropyl derivatives of guar gum, cellulose, and chitosan on the properties of natural hydraulic lime pastes. IOP Conf Ser Mater Sci Eng 2019;583:012009. https://doi.org/10.1088/1757-899X/583/1/012009.

[15] Groot CJWP. Effect of water on mortar brick bond. TU Delft, 1993. 